\title{
GuERrA E PAZ EM “PiERRE MENARd, AUTOR DO QUIXOTE”, DE JORGE LUIS BORGES
}

\author{
War and Peace in "Pierre Menard, author \\ of the Quixote", by Jorge Luis Borges \\ Guerra y Paz en "Pierre Menard, autor \\ del Quijote”, de Jorge Luis Borges
}

GUSTAVO NAVES FRANCO

http://dx.doi.org/10.1590/S2178-14942017000300007

Gustavo Naves Franco é mestre e doutor em História Social da Cultura pela Pontifícia Universidade Católica do Rio de Janeiro (PUC-Rio) e professor adjunto do Departamento de Letras da Universidade Federal do Estado do Rio de Janeiro (UNIRIO) (gnavesfranco@gmail.com)

Artigo recebido em 1 de junho e aprovado para publicação em 30 de agosto de 2017. 


\title{
RESUMO
}

0 artigo propõe uma leitura de "Pierre Menard, autor do Quixote", conto publicado pelo escritor argentino Jorge Luis Borges em 1939, como uma sátira de hábitos e práticas de círculos literários franceses no momento que antecedeu a Segunda Guerra Mundial. Com a análise de matérias jornalísticas, resenhas e outros escritos do autor, seu comportamento diante da conjuntura política europeia do período é reconsiderado, conferindo ênfase a aspectos antes negligenciados pela crítica. Assim, as referências internas do conto são articuladas em uma chave interpretativa que pressupõe o debate sobre a guerra e a paz entre intelectuais da década de 1930.

PalaVras-CHAVE: Jorge Luis Borges; Literatura Argentina; Sátira; História Literária - sec. XX.

\begin{abstract}
The article proposes an interpretation of "Pierre Menard, author of the Quixote", the short story published by the Argentine writer Jorge Luis Borges in 1939, as a satire of habits and practices of French literary circles in the eve of the Second World War. With the analysis of newspaper stories, reviews and other writings of Borges, his positions on the European political scenario are reconsidered, with emphasis on aspects usually neglected by his commentators. Thus, the short story's internal references are articulated on an interpretative basis that presupposes the debate on war and peace between intellectuals of the 1930s.
\end{abstract}

KeYwORDs: Jorge Luis Borges; Argentine literature; satire; literary history - $20^{\text {th }}$ century.

\section{RESUMEN}

El artículo propone un análisis de "Pierre Menard, autor del Quijote", cuento publicado por el escritor argentino Jorge Luis Borges en 1939, como una sátira de hábitos y prácticas de los círculos literarios franceses en vísperas de la Segunda Guerra Mundial. Con el recurso a piezas periodísticas, reseñas y otros escritos de Borges, sus posturas relacionadas con el escenario político europeo son replanteadas, con énfasis en aspectos descuidados por sus críticos. Así, las referencias internas del cuento se articulan en una clave interpretativa que presupone el debate sobre guerra y paz en los diálogos intelectuales de los años treinta.

Palabras ClaVE: Jorge Luis Borges; literatura argentina; sátira; historia literaria - siglo XX. 


\section{INTRODUÇÃO}

$\mathrm{O}$

s estudos acadêmicos sobre a obra do escritor argentino Jorge Luis Borges com frequência enfocaram sua dedicação a discussões filosóficas e literárias. No entanto, a partir da década de 1990, e sem que estes eixos de análise tenham sido ignorados, foi incluído entre eles um esforço de compreensão mais diretamente relacionado ao contexto histórico em que suas narrativas foram elaboradas, e a que elas muitas vezes fazem referência. A publicação subsequente de diversos textos até então menos conhecidos do autor, através de coletâneas de resenhas e artigos para periódicos, só fez contribuir para a percepção da importância desta via interpretativa. Ainda assim, algumas das ênfases sugeridas pela conexão entre sua obra ficcional e estes textos de intervenção ou viés jornalístico foram até o momento pouco exploradas.

Deste modo, o pressuposto deste artigo é o de que, na releitura da obra de Borges, falta ainda considerar todas as implicações da sua evidente inquietude diante da situação geopolítica mundial na segunda metade da década de 1930. Este é sem dúvida um assunto de que nenhum escritor minimamente informado poderia deixar de tratar naquele período; mas, nas reuniões de escritos de Borges, nota-se, em particular a partir de 1936, uma recorrência do tema que não deixa de acompanhar a escalada da ameaça de um conflito na Europa. E esta proeminente preocupação foi ainda maior no momento em que a guerra estava por ser deflagrada, tendo como desdobramento mais imediato as sucessivas vitórias alemãs nas frentes de batalha. Vale ressaltar, então, que justamente em 1939 Borges publicou um dos seus mais célebres contos, o "Pierre Menard, autor do Quixote".

Naturalmente, a mera datação do texto não seria suficiente para articulá-lo ao contexto histórico que se quer colocar em discussão. Porém isto será feito, no decorrer da análise, com a verificação de alguns de seus procedimentos estilísticos e com o esclarecimento de vínculos entre este conto e outros textos do autor no período. Por outro lado, esta opção interpretativa apresenta um problema singular, relacionado à proeminência adquirida pelo texto para a elaboração e ilustração de certos tópicos da teoria literária até os anos 1990, inalterada mesmo na inflexão crítica das décadas seguintes. Pois, afinal, em "Pierre Menard" temos uma narrativa que veio a ser mobilizada justamente na defesa da autonomia da criação literária 
diante de quaisquer fatores conjunturais, e em discussões sobre a irrelevância da intenção autoral para a análise do texto de ficção.

Por isso, a reavaliação deste conto requer uma análise mais pontual do que a utilizada para situar a obra de juventude de Borges no ambiente político da Argentina dos anos 1920, tal como a realizada por Beatriz Sarlo (1993). Aí a contextualização podia ser pressuposta em linhas gerais, relacionadas a temas da tradição e do ambiente intelectual argentino, e o procedimento não apresentava um desacordo aberto com interpretações anteriores. Já no que se refere ao conto de 1939, Sarlo seguiu tratando-o como uma encenação de tópicos, enigmas e paradoxos da teoria literária, em consonância com caminhos indicados por Ana María Barrenechea em La expresión da la irrealidad en la obra de Borges, de 1957. Esta linha de compreensão é de fato válida para a leitura e análise de diversos textos do autor, em diferentes momentos de sua produção literária. Porém, considerando especificamente os escritos da segunda metade da década de 1930, o entendimento da obra de Borges como "expressão de irrealidade", em suas complexas especulações linguísticas, metafísicas ou filosóficas, pode adquirir uma outra conotação.

Em tal entendimento fica comprometida, sobretudo, a valoração positiva da "irrealidade" supostamente expressa nos contos do período, na medida em que vemos o autor caracterizar insistentemente como "fantásticos", destituídos de um "senso de realidade", alguns dos regimes e posicionamentos políticos que criticou na época em diferentes ocasiões. Do mesmo modo, seriam fantásticas e irreais, no limite do caricato e do ridículo, algumas das operações intelectuais e especulações filosóficas que acompanhavam alguns destes fenômenos. Daí a possibilidade de que a interpretação das ficções de Borges do período seja não apenas matizada através do procedimento de seu cotejo com outros textos, mas invertida em suas conclusões, com a chance de que, ao invés de serem tomadas como elogios da irrealidade e da fantasia, elas venham a ser lidas como sátiras e alegorias de um mundo fantasioso, entregue às quimeras de uma imaginação política ensandecida.

Esta inversão ficou por ser executada mesmo pelos críticos que atentaram para o interesse de Borges pelo ambiente político da Europa dos anos 1930 de maneira geral, e pelos desdobramentos da Segunda Guerra em particular. Daniel Baldernston (1993), assim como Annick Louis (2007), ao identificar na política um tema recorrente da obra de Borges, desenvolveram um valioso eixo investigativo, porém sem dar maior atenção a aspectos conjunturais e sem investir na delimitação de um ponto de vista para as reflexões e representações do autor a este respeito. Este ponto de vista, pode-se antecipar agora - para que seja rediscutido e reavaliado no decorrer do artigo -, era o de uma filiação a um pensamento de matizes britânicos, de caráter livresco e com traços de excentricidade, porém em última instância baseado 
em uma noção de common sense na qual um "senso de realidade", moderado e pragmático, cumpre um papel fundamental, de acordo com os atributos da formação pessoal e das afinidades intelectuais de Borges (cf. Hadis, 2006, e Franco, 2012). Atributos e afinidades que, por sua vez, foram inclusive acentuados pela conjuntura geopolítica com que ele se deparou em sua maturidade, e que poderão ser melhor explicados através da compreensão de suas relações com a obra e o pensamento do escritor britânico G. K. Chesterton.

Mais especificamente, no que se refere ao propósito anunciado, será necessário recorrer a The End of Armistice (1936), obra que reuniu os escritos de Chesterton sobre a conjuntura política da Europa nos anos anteriores à sua publicação, e que foi mais de uma vez mencionada por Borges para esclarecer seus raciocínios e posturas a respeito. Nela, observa-se não apenas a preocupação com o belicismo germânico em ascensão, como também a crítica do pacifismo francês, em seu idealismo, como uma postura política vaga e perigosa diante da ameaça alemã. A propósito, e seguindo a pista de um pequeno ensaio de Juan José Saer ("Borges Francófobo"), o crítico Sergio Pastormerlo (2007) já observou como "Pierre Menard" opera em um modo satírico quanto a certos hábitos oratórios e especulativos que Borges identificava com a intelectualidade francesa. Em um desdobramento desta percepção, pretende-se aqui indicar como o conto está vinculado não apenas aos hábitos e tendências difusas de uma tradição intelectual, mas também, e com especial importância, ao papel e às posições de intelectuais e artistas da segunda metade dos anos 1930 perante a ascensão do nazismo, e ainda mais exatamente em 1939, com a iminente deflagração da guerra.

Em resumo, os contos de Borges escritos no ambiente tensionado pelas evoluções do conflito europeu, mesmo ao apresentarem temas e discussões de grande amplitude e complexidade, não deixam de estar associados a eventos históricos bastante específicos, sobretudo a tomada de Paris pelo exército nazista e a subsequente ameaça de um ataque a Londres (neste ponto, teríamos a escrita e a publicação de "Tlön, Uqbar, Orbius Tertius", cuja análise demandaria outro artigo, mas que será também eventualmente citado neste). Vale então enfatizar que, além das fontes primárias a serem especificadas, a pesquisa contou também com o suporte das biografias de Borges escritas por Emir Rodríguez-Monegal (1978), Horacio Salas (1994), e Edwin Williamson (2006). Espera-se ainda que as conclusões a respeito do "Pierre Menard" indiquem a possibilidade de releitura de outros textos de Borges, não para restringir a interpretação dos contos a um viés contextualista, mas porque, em alguns casos, a atenção às circunstâncias mais imediatas de elaboração dos contos antes enriquece do que depaupera a experiência de sua leitura e análise.

Na primeira parte, a seguir, serão apresentadas críticas de Borges a escritores e intelectuais alemães que enunciaram alguns dos princípios do movimento nazista, e a reação de 
Chesterton a aspectos desta doutrina, em que era feita também uma crítica da posição de intelectuais franceses diante da ameaça germânica, na qual encontramos indícios das posições de Borges sobre o mesmo tema. Na segunda etapa, será enfocada a interlocução distanciada e irônica entre Borges e representantes das letras francesas nos anos 1930, bem como sua relação com personagens francófilos do ambiente intelectual de Buenos Aires, o que fornecerá os últimos subsídios para a leitura do conto de 1939. Nas considerações finais, alguns dos tópicos da interação entre estética e política discutidos no decorrer do artigo serão retomados mais pontualmente, com destaque para a mobilização da sátira como recurso formal e estilístico na obra de Borges.

\section{A guerra pela guerra, a paz pela paz}

$\mathrm{E}$ m março de 1936, a revista Nosotros fez circular entre escritores argentinos uma pergunta sobre a possibilidade de que o nazismo representasse, para a civilização ocidental, a ameaça de "uma catástrofe que só admite comparação com a ruína do Império Romano" (Bianchi e Giusti, 1936: 40). As respostas recebidas foram publicadas em sucessivos números da revista, sendo que a de Jorge Luis Borges apareceu já na edição de abril daquele ano. Nela, como em outros artigos do período, o autor ironizava a ideia de uma "civilização ocidental" que fosse um conjunto fechado de práticas e produtos culturais, qualificando-a como "uma desordem de ritos, inibições, lembranças, habilidades e hábitos" - o que, por outro lado, Ihe permitia fazer distinções entre as inibições, habilidades e hábitos associados a cada nacionalidade europeia (Borges, 2007[1936]: 343). Deste modo, ele aproveitou a oportunidade para falar sobre suas próprias afinidades e preferências, mencionando, diante da interrogação da revista, certa complacência diante de certos hábitos e valores que atribuía à tradição britânica, e elaborando uma crítica a aspectos correlatos da alternativa francesa.

"O inglês pode dizer: My country, right or wrong, mas não identifica os interesses do universo com os do Império Britânico", escreveu então Borges. "O francês, por outro lado, é o homem que identifica o interesse do universo com o da sous-prefecture" (Borges, 2007[1936]: 344). Ou seja: de um lado, estaria uma atitude declaradamente nacionalista, ciente de sua inserção em um mundo de desacordos e embates entre variantes do mesmo sentimento, e do outro uma perspectiva em que o destino do cosmo era confundido com o de uma subprefeitura local. 0 contraste, aí, estaria entre uma postura realista e pragmática, capaz de agir em caso de necessidade para defender a nação em risco, e um comportamento idealista, pretensamente cosmopolita, e por isso mesmo mais perigoso, uma vez que assim os valores mais particulares adquiriam o aspecto de imperativos universais. 
E àquela altura, apenas semanas antes da ocupação militar da Renânia pelo exército alemão, a conjuntura presumida pela resposta de Borges à questão da revista era clara o bastante para se perceber suas implicações nesta diferenciação. Entretanto, por força de seu ofício como resenhista de periódicos portenhos, os tópicos relacionados à possibilidade de um conflito armado (e ao comportamento das diferentes nações naquele momento) reapareceriam em seus textos muito mais através da discussão de obras literárias, ou de textos filosóficos, do que por meio de referências diretas ao cenário geopolítico mundial.

Assim, o tema do expansionismo bélico ganharia destaque, por exemplo, em uma breve análise crítica de Der Kampf als Inneris Erlebnis ("A Guerra como Experiência Interior"), de Ernst Jünger, autor mais recentemente analisado por Russel Berman como um caso exemplar da convergência de estética e política no modernismo alemão (Berman, 1988: 99-117). Borges resumiu um dos principais raciocínios do autor no seguinte trecho: "Para Jünger, a guerra não é um instrumento: é um fim. É a experiência mais intensa de que o homem é capaz; é uma atividade desinteressada com a arte ou a religião" (Borges, 2000 [1937a]: 70). Na sequência, as virtudes do instinto bélico, na visão do autor alemão, eram elencadas em outras equiparações com a experiência estética. Então o expansionismo militar nazista teria como fundamento não somente a necessidade de conquistas e anexações da geopolítica tradicional, mas também, e sobretudo, o estímulo à mais nobre atividade do corpo e do espírito.

Poucos meses depois de escrever sobre Jünger, referindo-se a Der Totale Krieg, de Erich Ludendorf, Borges apresentava com assombro uma extravagante tese resultante deste juízo: a de que, sendo a guerra a mais elevada expressão da vontade vital dos povos, as instituições políticas de uma nação deviam estar subordinadas às instâncias militares, que podiam ignorar as finalidades externas à própria mobilização bélica, constituindo assim uma esfera autônoma e destituída de qualquer entrave ao seu pleno desenvolvimento (Borges, 2005 [1938]: 360). De acordo com esta conclusão, a expansão territorial do Terceiro Reich deixava de ser um objetivo cujo alcance dependia da força do exército germânico, para tornar-se uma consequência das operações necessárias à manutenção do dinamismo desta força. Por este motivo, o iminente conflito tinha outro aspecto em relação a eventuais embates entre nações verificados anteriormente, quando a tentativa de ampliação de fronteiras determinava o uso do poder militar, e não o contrário. Ou, como escreveu também Ernst Jünger em Krieg und Krieger ("Guerra e Guerreiros"), citado por Walter Benjamin em um ensaio de 1930 sobre o autor: "A questão de saber em que século se luta, por que ideias e com que armas, desempenha um papel secundário" (apud 2012 [1930]: 64).

A propósito desta frase, Benjamin prosseguiu com o seguinte comentário: "Essa nova teoria da guerra, que traz escrita na testa sua origem na mais furiosa decadência, não é outra 
coisa do que uma desinibida extrapolação para temas militares da teoria da art pour l'art" (2012 [1930]: 64). E, naquela ocasião, Benjamin tampouco deixou de notar como a postulação da guerra como um fim em si mesmo repercutia o fundamento "mais questionável e abstrato" do discurso pacifista, em suas versões mais tísicas, na medida em que também aqui era estabelecida uma finalidade absoluta, independente de circunstâncias históricas e políticas. "O misticismo bélico e o ideal estereotipado do pacifismo são, portanto, equivalentes", concluía o ensaísta (2012 [1930]: 64).

Misticismo bélico e ideal estereotipado do pacifismo que nos anos seguintes viriam a ser associados pelo escritor inglês G. K. Chesterton a tendências intelectuais germânicas e francesas, respectivamente. Considerando então a enorme influência de Chesterton na trajetória intelectual de Borges, cabe analisar seus raciocínios neste sentido. E já em 1933 Chesterton defenderia a necessidade de que a Grã-Bretanha tivesse uma linha de ação melhor definida em relação à Alemanha para corrigir o estrago feito, em grande parte por ela mesma, no final da guerra anterior. Pois, segundo Chesterton, nenhuma verdadeira vitória poderia pretender ser absoluta; a qualquer tipo de conquista deve corresponder uma perda, e certo grau de frustração é inerente a todas as realizações humanas. Com isso, tampouco a vitória se converteria em um orgulhoso instrumento de humilhação, que causasse a emergência de um antagonismo fanático da parte dos derrotados. Este preceito, como sabemos, havia sido ignorado no Tratado de Versalhes, no final da Primeira Guerra. Mas, para ele, isto demandava uma lúcida ação restauradora da ordem internacional em crise, e não a passividade culpada sob disfarces pacifistas.

Trata-se então de analisar alguns ensaios na sequência de leitura proposta em The End of Armistice (1936). E antes de tudo, em "Who is dictator?", "The heresy of race", "The truth about tribes", e "One word more", examina-se a diferença entre a Nação e a Raça como critérios para o estabelecimento de unidades políticas. Pois estava claro para Chesterton que 0 nazismo, em vez de caracterizar-se por uma já conhecida vaidade nacionalista, havia transformado e distorcido este sentimento através do orgulho racial - em que o indivíduo, purificado de máculas exógenas, está vinculado a uma linhagem sanguínea, que configura uma imagem sacralizada do clã. Em decorrência disto, todo homem se torna aquilo que ele próprio venera: algo essencialmente distinto, em sua opinião, do respeito por uma bandeira, que representaria uma instância mediadora e separada do homem, a qual pressupõe o reconhecimento de outras unidades fundadas sobre o mesmo princípio, e seria, em condições regulares, compatível com a humildade pessoal.

Por sua tendência a transformar-se em um absoluto, portanto, o dado racial, segundo Chesterton, ignoraria todas as fronteiras estabelecidas, substituindo os múltiplos preconceitos 
e valores de cada nação pela indefinida sensação do indivíduo de pertencimento a uma comunidade eternizada. Borges faria o mesmo raciocínio em um texto de 1940, referindo-se a "perigosos etnólogos" alemães, que defendiam anexação de outros países não apenas quando consideravam os seus povos como uma raça inferior, mas também quando afirmavam o profundo enraizamento destes na raça germânica (1940: 179).

Mas vejamos também como o universalismo pacifista era abordado no livro de Chesterton. E, quanto a isto, em "Third thoughts are best", o autor manifestava uma de suas principais preocupações: "O panorama europeu é sombrio; e tudo indica que os pacifistas conseguirão nos arrastar para a guerra" (1987 [1936]: 626). Pois, na medida em que o rearmamento britânico era protelado, em razão de uma confiança cega na doutrina da harmonia de interesses, ou simplesmente por causa da hesitação gerada pela memória da catástrofe anterior, a guerra tornava-se cada vez mais provável, tendo em vista que os alemães não se sentiriam coagidos a manter suas pretensões dentro de certo limite. E Chesterton identificava no âmbito francês uma tendência particularmente doentia à inação, de tal maneira contrastante com os impulsos vitais germânicos que chegava a ser seu reverso perfeito, gerando com isso uma verdadeira cumplicidade entre duas inclinações diametralmente opostas. Então, depois de relembrar um famoso encontro entre Voltaire e Frederico II, em "The evil friendship", ele observava em outro ensaio: "O pacifista e o prussianista se complementam perfeitamente (...) Não me surpreende que, na prática, eles tenham formado uma aliança" (1987 [1936]: 651).

Suicídio e destruição: neste binômio residia para Chesterton a cumplicidade entre pacifismo e belicismo. 0 que ele sugeria, desde logo, não era um imediato e desgovernado ataque militar inglês à Alemanha, mas a criação de condições em que exigências pudessem ser feitas ao regime nazista; o que, por outro lado, não excluía a disposição para o embate armado, se não houvesse um ambiente de racionalidade e pragmatismo suficiente de ambas as partes para evitá-lo.

Borges, além de ter acompanhado ou referendado os argumentos de Chesterton em resenhas e comentários isolados, viria a demonstrar um crescente acordo em relação à necessidade do rearmamento e da resistência inglesa para conter o nazismo. No natal de 1940, chegou inclusive a publicar na revista Saber Vivir um poema intitulado "Para la noche del 24 de diciembre, em Inglaterra", no qual se referia à "grande sombra de Dickens" (o "último grande homem", na expressão de Chesterton) como um estímulo e uma fonte de energias para que os britânicos conseguissem superar a situação em que se encontravam (2007 [1940b]: 183). Mas, já em 1938, o argentino publicara na revista Sol y Luna uma tradução de "Lepanto", poema de Chesterton sobre as cruzadas e a defesa da cristandade - e este gesto, mais do que nenhum outro até aquele momento, indicava sua adesão ao ponto de vista do escritor inglês (2007 [1938]: 168-177). 


\section{AS ARMAS E AS LETRAS}

V

amos agora analisar como o próprio Borges fez referência a figuras e obras importantes do ambiente literário francês dos anos 1930. E, neste ponto, torna-se relevante uma outra matéria da revista Nosotros, também de 1936, em que o editor Roberto Giusti descrevia um congresso de escritores ocorrido em setembro daquele ano na capital argentina. 0 encontro havia sido convocado em caráter extraordinário pelo Pen Club International (a associação internacional de escritores fundada no início do século pelo escritor inglês $\mathrm{H}$. G. Wells, entre outros), e tinha como finalidade a realização de um debate sobre a disseminação do fascismo e suas implicações para a atividade literária naquele momento. Mas autores como Thomas Mann, George Bernard Shaw e o próprio Wells alegaram razões particulares para não comparecer, de modo que as delegações italiana e francesa tiveram a oportunidade de ocupar o palco armado para o congresso, lideradas, respectivamente, por F. T. Marinetti e Jules Romains.

0 confronto destes dois personagens acabou se tornando predominante nos relatos a respeito do congresso, com Marinetti defendendo a legitimidade do fascismo, em surtos histriônicos, e Romains adotando uma postura pacifista, mas não menos performativa. Giusti inclusive descreveria o discurso de abertura de Romains como um momento de "grande beleza e dramaticidade", em que o antagonismo democracia versus ditadura era proclamado, com a subsequente expressão do sonho de "uma liberdade iluminada pelo espírito" que fizesse vibrar, harmonicamente, na alma de todos, o desejo da paz mundial. Para ilustrar suas impressões, o cronista acrescentou ainda a citação de um artigo poético que o próprio Jules Romains publicou depois em La Prensa. Neste, o francês lembrava a "reação imediata de alegria e gratidão do público" quando ele declarou sua crença na causa da emancipação humana (Giusti, 1936: 48-64).

Isto será o suficiente para avaliarmos a resenha de L'homme blanc, do próprio Jules Romains, publicada por Jorge Luis Borges na revista El Hogar em setembro de 1937. Nela, Borges fazia referência à participação do escritor no congresso do Pen Club; porém, a respeito da obra comentada, a resenha não apresentava o mesmo entusiasmo do público do evento. Alguns versos específicos eram citados: "Fin de toute oppression. L'homme délivre de I'homme. I Régne du droit sur la force, et du travail sur l'argent./ Pleine respiration de la foule inteligente" - e, ao criticá-los, o resenhista lamentava que o poeta tivesse recaído na mera oratória (2005 [1937b]: 337-8). Algo que, em sua visão, seria cada vez mais comum na literatura francesa, ou na literatura argentina de traços francófilos daquele período.

Mas, por outro lado, a especificação temporal deve servir também para afirmarmos que o respeito de Borges pela literatura e o pensamento francês de outras épocas permaneceu 
inalterado. Podemos atribuí-lo ao que ele chamou na mesma época de a "secular amizade entre as letras da Inglaterra e da França", ilustrada em uma resenha com a admiração de Shakespeare por Montaigne, e a influência de Jonathan Swift sobre Voltaire (2005 [1937b]: 276-7). De modo que, no século $X X$, e em particular no entre-guerras, esta amizade estaria sendo rompida pela prática da mera elegância estilística entre os franceses ou de um virtuosismo técnico que desembocavam na criação de complexas e extravagantes engenhocas literárias. Ao mesmo tempo, a intelectualidade parisiense do período havia se distinguido por livros de orientação pacifista como Au-dessus de la mêlée (1915), de Romain Rolland, ou voltando-se para a defesa de valores atemporais como a Justiça e a Liberdade, na linha do La Trahison des clercs, de Julien Benda (1927).

Estas informações terão ressonância na releitura aqui proposta para "Pierre Menard". Porém igualmente importante será uma breve descrição de um outro fenômeno da cultura argentina que, também no final dos anos 1930, trazia a lembrança de hábitos e práticas do ambiente literário de Paris: o elegante salon littéraire de Victoria Ocampo, integrante de uma tradicional família oligárquica de Buenos Aires, responsável também pela criação da revista Sur em 1931. Um dos eixos editorais da revista (e também um tema de debate recorrente no salão literário de Ocampo) era o princípio da autonomia da arte, tal como postulado pelo simbolismo francês, que favorecia justamente o virtuosismo técnico na elaboração do objeto estético, e a discussão teórica de seus mecanismos internos.

Borges nunca foi um frequentador assíduo daquelas reuniões, em que se destacavam figuras de maiores recursos oratórios, como o poeta Oliverio Girondo. Não obstante, a habilidade que possuía para a formulação de problemas lógicos e a exposição de sistemas metafísicos se mostraria bastante adequada ao periódico. Os ensaios por ele publicados em Sur em geral tornaram-se peças de investigação filosófica ou linguística, ou comentários sobre obras de autores até então pouco conhecidos na Argentina. Também para Sur ele podia enviar traduções sem muito apelo comercial, mas de uma peculiar qualidade técnica, que implicavam o emprego de um esforço considerável em uma atividade de teor lúdico e amadorístico.

De modo que, quando instado a escrever sobre a fundadora da revista, além de enfatizar a ousadia, o caráter forte, e mesmo o autoritarismo de Victoria, Borges lembrou que ela "via na cultura um prazer, um complexo agrado do ócio, nunca uma obrigação" (apud Chiappini, 1994: 18). Mas neste elogio estava implícito um diagnóstico do caráter aristocrático da dama da elite de Buenos Aires - enquanto Borges, funcionário público lotado em uma biblioteca suburbana (até ser destituído do cargo pelo governo de Juan Domingo Perón), nunca deixou de depender da literatura como meio de vida, por mais que se dedicasse à elaboração de complexos artifícios e ficções nas muitas horas vagas do trabalho na biblioteca. Além disso, 
havia a identificação de Borges com aspectos da cultura burguesa britânica e oitocentista que, da perspectiva já indicada na leitura de Chesterton, vieram a adquirir maior ressonância no contraste com o grupo da revista Sur.

Isto nos ajuda a compreender por que, em uma conversa com Adolfo Bioy Casares (com quem teve uma amizade mais próxima e duradoura), o escritor argentino diria o seguinte sobre o livro Diálogos con Borges, publicado por Victoria Ocampo em 1969: "Me mostra com Victoria Ocampo, na inauguração de Sur, em um aniversário de Sur, com o conde de Seyès e com a condessa de Cuevas: eu não imaginava que tivesse tido uma vida tão estranha" (apud Casares, 2006: 1268). E este irônico estranhamento de sua convivência com figuras de título nobiliárquico repercutia, então, elementos de uma ironia que, como logo veremos, foi predominante na escrita do conto publicado 30 anos antes.

Mas Victoria era conhecida também como detentora de uma inteligência mordaz, e por sua capacidade de organizar um ambiente de vívido convívio social, em oposição ao comportamento de Borges, que podia ser também tomado como uma expressão de esnobismo com matizes britânicos. Pois ao evitar a indiscrição e a associação a grupos literários, ele cultivava uma reserva passivel de ser compreendida como indiferença e até como arrogância perante as "frivolidades" alheias. Daí o seguinte comentário de Victoria a seu respeito: "Em relação a Borges, levo uma vantagem: eu o conheço. A recíproca é improvável. E o admiro. A recíproca é impensável" (apud Chiappini, 1994: 13).

E com isto temos todos os elementos necessários para analisar, enfim, o conto em que se cristalizaram vários dos aspectos até aqui mencionados. Pois antes de tudo é preciso enfatizar que "Pierre Menard, autor del Quijote" apareceu na revista Sur de maio de 1939. Dado o histórico das relações entre Borges e Ocampo, é improvável que ela não tenha percebido a ironia, mas é também bastante possível que tenha aceitado a brincadeira, sem apresentar restrições à publicação do texto. 0 conteúdo do texto é bem conhecido, mas alguns detalhes de sua trama e estilo precisam ser ressaltados.

A princípio, o narrador se refere ao conjunto da obra de um falecido escritor, o Pierre Menard do título, apresentando-a como o motivo de sua intervenção, sobretudo depois das supostas omissões e adições a ela impugnadas no catálogo de um jornal protestante (grifo no original) - mesmo que os "deploráveis leitores" deste veículo fossem certamente poucos, além de "calvinistas ou circuncisos". Ele então declara, em uma retórica caricatamente elevada: "Dir-se-ia que ainda ontem nos reunimos diante do mármore final e entre os ciprestes infaustos, e já o Erro trata de conspurcar sua Memória... Decididamente, uma breve retificação é inevitável". E, para tanto, são evocados dois "altos testemunhos". Primeiro, o da baronesa de Bacourt, em cujos "inesquecíveis vendredis" o próprio narrador teria tido a honra de conhecer 
Pierre Menard. E depois, o da condessa de Bagnoregio, um dos "mais refinados espíritos do principado de Mônaco", que teria sacrificado à "veracidade ou à morte" - segundo as palavras da condessa - a reserva que a distinguia, ao enviar para a revista Luxe uma carta aberta sobre o assunto (Borges, 2005 [1939]: 475-482).

Isto é o suficiente para qualificar o estilo satírico do texto e sua terminologia como uma paródia sequer muito sutil da linguagem utilizada nos elegantes círculos literários de Buenos Aires e Paris (com insinuações de um antissemitismo que de fato não deixava de estar presente ao menos no cenário francês também, de acordo com o estudo de Alice Yaeger Kaplan, Reproductions of Banality: Fascism, Literature, and French Intellectual Life, de 1986). E, em seguida, no conto, surge a verdadeira lista da "obra visível" de Menard, na qual se destacam sonetos simbolistas, um exame das leis métricas essenciais da prosa francesa, monografias sobre Descartes e Leibniz, discussões sobre a técnica do xadrez etc. Nela haveria também uma invectiva contra Paul Valéry, que, segundo o narrador, seria o "reverso exato" da verdadeira opinião de Menard sobre o poeta, com quem ele teria uma "antiga amizade", a qual permitiria esta inversão retórica. Valéry, por sinal, foi identificado por Juan José Saer como o melhor exemplo da persona literária satirizada por Borges neste conto, não apenas por uma questão de antipatia pessoal, mas também em função do fascinado interesse do argentino pelas "extraordinárias" maquinações do autor do poeta francês (Saer, 2004 [1992]: 30-37, e Pastormerlo, 2007: 95-114).

Mas o extraordinário neste caso, como Saer observou, para Borges referia-se também a excessos que podiam ter como único objetivo a afetada exibição de habilidades fora do comum. "Meu propósito é meramente assombroso", teria dito Menard, enfim, sobre aquela que seria sua hoje célebre "obra invisível": a reescrita, palavra por palavra, do Dom Quixote de Miguel de Cervantes, não através da recriação das condições de sua elaboração original - um procedimento descartado por ser "demasiado fácil" -, mas como resultado de uma sofisticada operação mental, comparável a uma "demonstração teológica ou metafísica". Neste sentido, a opção pelo Quixote só ressaltaria o contraste entre um romance escrito em um estilo descontraído, que beirava a negligência, e que exatamente por isso causava encantamento (como Borges tratava a prosa de (ervantes), e o livro que sairia da pena de Menard, plenamente articulado pela necessidade, o que o tornaria um tesouro para a análise crítica de cada um de seus elementos internos. A este tipo de análise procede então o narrador do conto, tendo diante de si alguns esboços e fragmentos recuperados, muito mais "sutis" do que os seus correspondentes cervantinos, o que seria supostamente revelado no cotejo das versões de ambos os escritores.

Mas não é o caso, aqui, de levarmos muito a sério o projeto literário de Pierre Menard explicando-o em todos os seus pressupostos e implicações. Isto, em parte, porque ele já foi 
objeto de um exaustivo escrutínio por parte da crítica dedicada à obra de Borges; mas também porque, ao observar os aspectos satíricos do conto, estamos justamente verificando o que há de patético em todas estas minúcias. Portanto, a gravidade e os escrúpulos com que o assunto é tratado pelo narrador do texto reencenam em outra chave o pedantismo de seus primeiros parágrafos. Mas há uma passagem que, para nossos propósitos, merece maior atenção. Nela, é discutido o capítulo XXXVIII da primeira parte do livro, o "que trata do curioso discurso que fez Dom Quixote sobre as armas e as letras" - a favor das armas e contra as letras em Cervantes, e igualmente elaborado, por diferentes motivos segundo o narrador, em Pierre Menard.

Há então uma digressão a respeito desta dinâmica de semelhanças e diferenças. No primeiro caso, o de Cervantes, o narrador atribui o conteúdo do discurso ao fato de que 0 autor da obra era um velho militar; já no segundo, é com algum espanto que o crítico encontra uma argumentação daquele teor em "um contemporâneo de La Trahison des Clercs e de Bertrand Russell". Mas termina por aceitar a explicação da boronesa de Baucourt, que evoca a influência de Nietszche, e, ao mesmo tempo, recorda a invectiva de Menard contra Paul Valéry, para assinalar uma característica consonante com a "divina modéstia" do autor: o hábito de propagar ideias que eram o estrito reverso das preferidas por ele mesmo. Assim, depois de um longo trecho, fica muito pouco claro qual seria a alternativa defendida por Menard, o que não deixa de servir a uma última observação do comentarista: "0 texto de Cervantes e o de Menard são idênticos, mas o segundo é quase infinitamente mais rico (mais ambíguo, diriam seus detratores; mas a ambiguidade é uma riqueza)". Em contraste com a escrita vulgar de Cervantes, portanto, a fineza do estilo de Menard permitia um jogo com os signos literários em que estes perdiam substância para poderem ser livremente transfigurados em seus opostos. No artefato estético, guerra e paz eram polos indistintos, intercambiáveis, ambos submetidos a uma nobre e desinteressada atividade artística.

E, no final do conto, ao apresentar a justificativa de uma tarefa que reconhece como "complexíssima e de antemão fútil", o narrador equipara aquela atividade a uma "confissão" de "nossa languidez ou nossa barbárie". Neste caso, que a inação e a violência sejam enunciadas como vetores equiparáveis mais uma vez remete à aliança entre suicídio e devastação, tal como diagnosticada por G. K. Chesterton em The End of Armistice. E, diante disso, o discurso de Menard a favor das armas já não é tão deslocado ou surpreendente como poderia parecer: ele faz repercutir a indiferenciação entre o belicismo alemão e algumas vertentes do pacifismo difundidas na França antes da guerra, apontadas por Chesterton e Walter Benjamin. Para reforçar o argumento, a simples e breve nota final do narrador é determinante: "Nîmes, 1939".

Fica ressaltado então que, ao elaborarmos uma análise em torno da conjuntura europeia do final dos anos 1930, o contexto histórico a que nos referimos é sobretudo o contexto 
do narrador de "Pierre Menard" - ou seja, aquele assinalado por Borges como referência para o entendimento de seu jogo de alusões, movimentos satíricos e citações literárias. Mais importante que o fato de o conto ter sido escrito e publicado em 1939, portanto, são a data e a localização que surgem como fatores internos da narrativa. E a relevância de ambas não pode ser subestimada; elas dizem respeito não apenas a um conjunto de hábitos e práticas culturais, como também, e talvez sobretudo, ao modo como estes hábitos e práticas transcorriam em meio à iminente deflagração de um conflito armado de enormes proporções.

Em setembro daquele ano começaria a Segunda Guerra Mundial. Em maio de 1940 as tropas alemãs passaram a avançar em um ritmo implacável na direção de Paris. Até aquele momento, nenhum outro fato demonstrara de modo tão intenso as reais possibilidades de um triunfo da vontade prussiana, e a queda da capital francesa, poucas semanas depois, confirmou o sucesso de uma operação impetuosa e arriscada. Mas a velocidade com que a vitória foi conquistada só foi possível diante do despreparo das forças oponentes, no ambiente de irreal "normalidade" que precedeu a invasão na França. Pois, em geral, muitos cidadãos franceses, entre eles artistas e intelectuais, sequer se deram conta da situação até que fossem instados à capitulação ou à fuga. E a própria Victoria Ocampo, na distante Buenos Aires, segundo o relato do historiador Túlio Halperin Donghi, se tornaria uma exasperada anfitriã de fugitivos da catástrofe, comentando com assombro como seus hóspedes teriam passado seus últimos dias em solo francês a discutir o cumprimento ideal das cortinas, ou uma lista das mulheres mais bem vestidas de Paris (2004: 164).

A esta lista poderíamos acrescentar o debate sobre as complexíssimas maquinações literárias de um obscuro escritor recentemente falecido em Nîmes, ao considerar a especificidade de tempo e espaço indicada por Borges para sua narrativa. Porém estas discussões não eram totalmente inocentes em sua inconsequência: ao estipular a equivalência das armas e das letras, da paz e da guerra, chegando inclusive a defender o uso das armas e as inclinações bélicas entre as minúcias de seus postulados (para que uma interpretação subsequente revertesse esta defesa em seu contrário), elas criavam um ponto de contato entre dois extremos que, do ponto de vista britânico, viriam de fato a comportar-se como cúmplices e complementares.

Para Jorge Luis Borges, a principal lembrança que ficaria do momento da invasão de Paris seriam relatos segundo os quais membros da elite teriam "recebido" as forças de ocupação, sem ocultar certo júbilo com o fato de que finalmente alguma coisa estava revertendo o estado de letargia e irrealidade em que o país estava submerso. "Estes nazis franceses, estes partidários da violência, nunca me pareceram muito coerentes", ele diria para Bioy Casares em 1966 (2006: 1103). Incoerentes não, ambíguos - teria respondido o narrador de "Pierre Menard". 


\section{CONSIDERAÇÕES FINAIS}

$\Lambda$ s relações entre a produção literária de uma época e seu ambiente histórico são tão criativa permite que os nexos entre texto e contexto sejam com frequência extremamente sutis, de modo que sua construção pela crítica dependa do entendimento de amplos processos culturais e de certos detalhes estilísticos. No entanto, em algumas situações especiais, determinadas circunstâncias históricas surgem em um artefato estético de maneira ao mesmo tempo insidiosa e evidente, tornadas ocultas pelo mesmo processo que as determina como chave de leitura inescapável. Este é o caso, com frequência, da sátira e da alegoria políticas, que requerem a percepção de certas argúcias formais para serem analisadas, em sua ostensiva e igualmente secreta referência a um elemento externo claramente determinável.

Estas argúcias estão presentes, como foi indicado, no "Pierre Menard", uma sátira do ambiente literário francês no momento que antecedeu a eclosão da segunda Guerra; e seriam igualmente importantes, pouco depois, na elaboração de "Tlön, Uqbar, Orbius Tertius", de 1940, conto muitas vezes lido como expressão do fantástico e da irrealidade na obra de Borges, mas que traz todos os elementos da alegoria de um mundo nazificado, isto é, de uma realidade tornada "fantástica" pela ação de uma sociedade secreta (como foi observado antes, este texto poderia ser objeto de uma análise semelhante à praticada aqui com "Pierre Menard", através do entrelaçamento com outros escritos menos conhecidos do mesmo período - mas, por questões de espaço e de concentração na leitura de um relato, optou-se aqui por esta breve referência). Por outro lado, se as circunstâncias atípicas vividas naquele par de anos foram decisivas para a definição do tema e da forma de seus textos, o mesmo não necessariamente aconteceria em outros momentos de sua trajetória literária. Assim, o que vale para o estudo destes dois textos não precisa ser transposto à análise de toda a obra do autor, pois as relações entre a produção literária e o ambiente histórico são tão variáveis quanto a força das circunstâncias para imporem-se como único objeto possível da elaboração estética.

A sátira e a alegoria políticas são muitas vezes, afinal, reações artísticas a cenários muito tensionados e desesperadores; e são também recursos característicos dos epígonos de longas tradições culturais, na medida em que se tornam cada vez mais reativos àquilo que percebem como degradação e decadência nos trâmites sociais e intelectuais de seu tempo. Ambos os fatores, vale ressaltar, contribuíram para que Borges recorresse aos gêneros literários empregados em "Pierre Menard" e em "Tlön": por um lado, ele estava de fato aterrorizado com a situação que vinha acompanhando pela leitura dos jornais e em alguns círculos portenhos, e por outro, como uma articulador de certos hábitos e práticas britânicos (é verdade que 
um tanto anacrônico e deslocado), a sátira e a alegoria se tornaram gêneros particularmente apropriados para que, do ponto de vista do common sense, ele representasse como risíveis ou insanas algumas das alternativas aristocráticas ou guerreiras que se apresentavam diante do declínio do mundo burguês oitocentista.

Já em 1945, quando começou a conceber o célebre conto "El Aleph", Borges se veria em condições de rearticular sua obra de acordo com outros parâmetros e propósitos estéticos. Mas isto, por contraste, só reforça a percepção de que, durante toda a Segunda Guerra Mundial, e particularmente nos primeiros momentos do conflito, ele praticamente não tinha outro assunto em seus escritos. Que tenha optado por apresentá-lo de formas eventualmente cifradas, oferecendo apenas alusões e pistas do tema essencial de suas narrativas do período, foi uma atitude característica do ponto de vista adotado em relação aos fenômenos de que tratava, e também uma exigência dos gêneros literários que escolheu para a apresentação. Porém, em diversos outros escritos, o autor deixou bastante claras suas preocupações. Recorrer a estes textos é trabalho da crítica que, sem deixar de buscar na obra do autor valiosas discussões de temas metafísicos e teóricos, esteja ao mesmo tempo interessada em compreender as aflições mais mundanas e circunstanciais do escritor Jorge Luis Borges.

\section{REFERÊNCIAS BIBLIOGRÁFICAS}

BALDERSTON, Daniel. Fuera de contexto? Referencialidad histórica y expresión de la realidad en Borges. Rosario: Beatriz Viterbo Editora, 1996 (1993).

BARRENECHEA, Ana Maria. La expresión de la irrealidad en la obra de Borges. Buenos Aires: Centro Editor de América Latina, 1984 (1957).

BENJAMIN, Walter. Teorias do fascismo alemão. Sobre a coletânea Guerra e Guerreiros, editada por Ernst Junger (1930). In: Obras escolhidas. Volume 1: Magia e técnica, arte e política. Trad. Sergio Paulo Rouanet. São Paulo: Brasiliense, 2012, p. 63-76.

BERMAN, Russel A. Modern culture and critical theory: art, politics, and the legacy of the Frankfurt School. Madison: The University of Winscosin Press, 1988.

BIANCHI, Alfredo y GIUSTI, Roberto. "Encuestas de Nosotros". Nosotros, segunda época, año I, n. 1, tomo I, Buenos Aires, abril de 1936.

BORGES, Jorge Luis. Pierre Menard, autor del Quijote (1939). In: Obras Completas. Buenos Aires: Emecé Editores, 2005, vol. 4, p. 475-482.

— América y el destino de la civilización occidental [Nosotros, Buenos Aires, Año I, Número I, abril de 1936]. In: . Textos recobrados 1931-1955. Buenos Aires: Emecé Editores, 2007 (1936), p. 342-3.

. 'Ce Vice Impuni, la Lecture', de Valéry Larbaud [El Hogar, 19 de febrero de 1937]. In : Obras Completas. Buenos Aires: Emecé Editores, 2005 (1937a), vol. 4, p. 276-277. 
'L'Homme Blanc', de Jules Romains [El Hogar, 17 de septiembre de 1937]. In : Obras Completas. Buenos Aires: Emecé Editores, 2005 (1937b), vol. 4, p. 337-8.

__. 'Der Kampf als Inneris Erlebnis', de Ernst Junger [El Hogar, 1 de octubre de 1937]. In: Borges en El Hogar 1935-1958. Buenos Aires: Emecé Editores, 2000 (1937c), p. 70-71.

__. 'Der Totale Krieg', de Erich Ludendorff [El Hogar, 21 de enero de 1938]. In: Obras Completas. Buenos Aires: Emecé Editores, 2005 (1938), vol. 4, p. 360-1.

—_. Algunos pareceres de Nietzsche [La Nación, Buenos Aires, 11 de febrero de 1940]. In: Textos Recobrados 1931-1955. Buenos Aires: Emecé Editores, 2007 (1940a), p. 178-182.

Para la noche del 24 de diciembre de 1940, en Inglaterra [Saber Vivir, Buenos Aires, n. 4/5, noviembre/ diciembre de 1940]. In: Textos Recobrados 1931-1955. Buenos Aires: Emecé Editores, 2007 (1940b), p. 183

CASARES, A. B. Borges. Edición al cuidado de Daniel Martino. Buenos Aires: Destino, 2006.

CHESTERTON, G. K. Lepanto. Traducción de Jorge Luis Borges. [Sol y Luna, Buenos Aires, n. 1, 1938]. In: BORGES, J. L. Textos Recobrados 1931-1955. Buenos Aires: Emecé Editores, 2007 (1938), p. 168-177.

—. The End of Armistice (1936). In: Collected Works V: Family, Society, Politics. San Francisco: Ignatius Press, 1987 (1936).

CHIAPPINI, Julio. Borges y la Revista Sur. Buenos Aires: Zeus, 1994.

DONGHI, Tulio Halperín. La Argentina y la Tormenta del Mundo: ideas e ideologías entre 1930 y 1945. Buenos Aires: Siglo XXI Editores Argentina, 2004.

FRANCO, Gustavo N. Falando para as Paredes: a questão nacional argentina em um discurso radiofônico de Jorge Luis Borges. Revista Eletrônica da Anphlac, n. 12, jan.-jul. 2012, p. 9-32.

GIUSTI, Roberto F. El Congreso de los P.E.N. Clubs. Comentario a puertas cerradas. Nosotros, segunda época, año II, tomo II, n. 6, setiembre de 1936, p. 48-64.

HADIS, Martín. Literatos y excéntricos: los ancestros ingleses de Jorge Luis Borges. Buenos Aires: Editorial Sudamericana, 2006.

KAPLAN, Alice Yaeger. Reproductions of banality: fascism, literature, and French intellectual life. Minneapolis: University of Minnesota Press, 1986.

LOUIS, Annick. Borges face au fascisme: les fictions du contemporain. La Courneuve: Aux Lieux d'Être, 2007.

PASTORMELO, Sergio. Borges crítico. Buenos Aires: Fondo de Cultura Económica, 2007.

RODRÍGUEZ-MONEGAL, Emir. Jorge Luis Borges: a literary biography. New York: E. P. Dutton \& Co., 1978.

SAER, J. J. Borges francófobo (1992). In:___. El concepto de ficción. Buenos Aires: Seix Barral, 2004 (1992), 30-37.

SALAS, Horacio. Borges, una biografía. Buenos Aires: Emecé, 1994.

WILLIAMSON, Edwin. Borges: una vida. Trad. Elvio E. Gandolfo. Buenos Aires: Seix Barral, 2006. 